\title{
Diversity of Phytophagous and Entomophagous Insect on Yellow Alder Flower (Turnera subulata J.E SM and Turnera ulmifolia L.) Around The Palm Oil (Elaeis guineensis J.) Plantations
}

\author{
Ryan Hidayat ${ }^{1 *}$, Chandra Irsan $^{2}$, Arum Setiawan $^{3}$ \\ 1Enviromental Management Department, Graduate School of Sriwijaya University, Jl. Padang Selasa No. 524 Bukit Besar Palembang Sumatera Selatan 30139, Indonesia \\ ${ }^{2}$ Department of Agriculture, Universitas Sriwijaya, Inderalaya, Jl. Palembang - Prabumulih KM.32 Kabupaten Ogan Ilir, Sumatera Selatan, Indonesia \\ ${ }^{3}$ Department of Biology, Universitas Sriwijaya, Inderalaya, Jl. Palembang - Prabumulih KM.32 Kabupaten Ogan Ilir, Sumatera Selatan, Indonesia \\ ${ }^{*}$ Corresponding author: ryan.hidayat991@gmail.com
}

\begin{abstract} in range $0.738-0.752$.

Keywords

Entomophagous and Phytophagous Insects, Community Structure, Diversity Index
\end{abstract}

Yellow alder flower, with Indonesian name bunga pukul delapan, can influence the existence of phytophagous and entomophagous insect around any crops. The existence of these phytophagous and entomophagous insects would affect the diversity of predator and parasitoid insect species that come to these crops. This research was aimed to study the role of yellow alder flower in their influence of the presence of predatory and parasitoid insect that active in the Turnera subulata dan Turnera ulmifolia. The research was conducted at July to August 2017 in palm oil plantation of PT. Tania Selatan branch Burnai Timur 1 . The results showed that phytophagous insect found in the yellow alder flower belonging to 6 orders and 25 families. Meanwhile for the entomophagous insect, it was belonging to the 7 orders and 15 families. The diversity index in Turnera subulate and Turnera ulmifolia was in range of 0.063 and 2.912 or higher than 2 . The dominant index was low (in range of 0.091 to 0.125 ) and the evenness index was high enough

Received: 28 April 2018, Accepted: 12 July 2018

https://doi.org/10.26554/sti.2018.3.3.130-133

\section{INTRODUCTION}

The oil palm sector in Indonesia substantially contributes to the foreign exchange, compared to other oil and oil producing plants (Nasution et al., 2014). The existing palm oil plant in South Sumatera has an area of 866,763 hectares, with total production of fresh fruit bunches (FFB) of about 2.11 million tons per year. Total revenue from sales of fresh fruit bunches (FFB) reached $\mathrm{Rp} 4,923,213$ per hectare, per year or about 4,923 trillion rupiah per year (Asmani, 2014).

In the plantation area of oil palm, there are various types of insect pests and controlled using synthetic insecticides because it is easy and fast. A synthetic insecticide in addition to killing pests, is also known to kill natural enemies from pests. How to control pests without using synthetic insecticides can be done through the management of agro-ecosystems that increase biodiversity to create a balance between pests and natural enemies. According to Rahayu and Sulistyowaty (2014), the planting of cover crops such as T. ulmifolia in oil palm plantations is reported to increase entomophagous group insects (Predators and parasitoids) and reduce the population of caterpillar pests.
An increase in the parasitoid population in oil palm plantations can be done through conservation. Conservation can be done by providing feed and habitat for the parasitoid imago. Plants containing pollen can be utilized as feed providers and habitat of natural enemy populations (parasitoids and predators). Pollen can be used as a source of food, shelter, and breeding, before the main host or prey is present in the planting area (Tyas et al., 2016).

T. subulata and T. ulmifolia plants can be utilized as part of conservation or preservation of predator and parasitoid life (Kurniawati and Martono, 2015). According to Steenis (2006) the $T$. subulata plant is a yellow alder flower that has a yellow color on the flower, and T. ulmifolia plant is a yellow alder flower which has a white color on the flower. T. subulata and T. ulmifolia are plants that contain pollen and nectar. Pollen and nectar can be utilized as feed and habitat providers for predator and parasitoid populations. (Tyas et al., 2016).

Data and information on insects that come to yellow alder flower T. subulata and T. ulmifolia in oil palm plantations are still inadequate. Therefore, this study was conducted to investigate 
Table 1. Number of orders, families and species of phytophagous and entomophagous insects found in the yellow alder flower in the bloom and wilting phase

\begin{tabular}{ccccccc}
\hline \multirow{2}{*}{ Yellow alder flower phase } & \multicolumn{2}{c}{ Orde } & \multicolumn{2}{c}{ Family } & \multicolumn{2}{c}{ Species } \\
\cline { 2 - 7 } & $\begin{array}{c}\text { Turnera } \\
\text { subulata }\end{array}$ & $\begin{array}{c}\text { Turnera } \\
\text { ulmifolia }\end{array}$ & $\begin{array}{c}\text { Turnera } \\
\text { subulata }\end{array}$ & $\begin{array}{c}\text { Turnera } \\
\text { ulmifolia }\end{array}$ & $\begin{array}{c}\text { Turnera } \\
\text { subulata }\end{array}$ & $\begin{array}{c}\text { Turnera } \\
\text { ulmifolia }\end{array}$ \\
\hline Bloom & 7 & 7 & 30 & 13 & 220 & 47 \\
Wilting & 8 & 6 & 20 & 10 & 108 & 48 \\
\hline
\end{tabular}

the role of the yellow alder flower (T. subulata and T. ulmifolia) as living habitats of entomophagous and phytophagous insects in enhancing the biodiversity around palm trees (Elaeis guineensis J.) at PT. Tania Selatan East Burnai Branch.

\section{EXPERIMENTAL SECTION}

This research was conducted in oil palm plantations PT. South Tania and Integrated Research Laboratory of Sriwijaya University from July to August 2017. The research was conducted using purposive sampling method, and the research location was divided into 2 regions. Area A near the river waters there are 3 T. subulata, and 3 T. ulmifolia, and area B away from river water there are 3 T. subulata, and 3 T. ulmifolia.

Collection of phytophagous and entomophagous insects in each yellow alder flower was conducted using visual observation, plastic bag trap, sweep net (insect net), killing jar (killer tube), and d-vacum (insect vacuum). Each trap is laid in the morning, afternoon, afternoon and observed. Taking phytophagous and entomophagous insects from the trap device was performed 12 times for 6 weeks. The identification of phytophagous and entomophagous insects is performed on the basis of morphological features. The identification books used include (Kalshoven, 1981; Anderson, 1998; Zahradink et al., 1991).

Abiotic temperature and humidity factor data were collected at yellow alder flower using TH60 hybrid thermo hygrometer, and light intensity using LX 100 light meter. Each measurement was done in the morning, noon and afternoon then observed and calculated using Pearson non-parametrical correlation to know the effect of factor abiotic to the existence
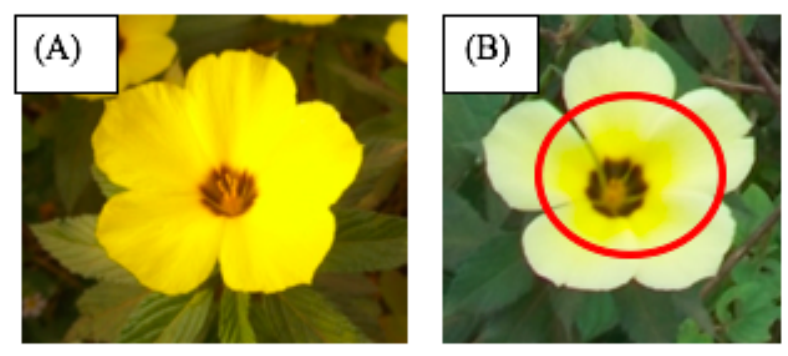

Figure 1. Yellow alder flower (A) Turnera subulata (B) Turnera ulmifolia and number of insects in the yellow alder flower.

The data of phytophagous and entomophagous insects obtained are shown in tabular form. The data obtained is used to determine the number of insects phytophagous and entomophagous. The data obtained were used to find out the index of diversity of phytophagous and entomophagous insects at yellow alder flower. The data obtained were used to find out the non-parametric correlation between the abiotic factors of temperature, humidity and light intensity on the number of insects at the yellow alder flower.

The species diversity index (Shannon Index) (Magurran, 1998), is calculated by the formula:

$$
H^{\prime}=-\Sigma P i \ln P i
$$

Where $\mathrm{H}^{\prime}$ is species diversity index, pi equals to $n i / N, n i$ is number of species individual, and $\mathrm{N}$ is the number of all the individual.

The criteria for the index value of species diversity based on shannon-wienner are as follows: species diversity is categorized as low if $\mathrm{H}^{\prime}>1$, medium if $\mathrm{H}^{\prime}=1-3$ and high if $\mathrm{H}^{\prime}>3$. (Fachrul, 2007).

The species dominance index is calculated by the Simpson formula (Indriyanto 2010):

$$
D=\Sigma\left(\frac{n i}{N}\right)^{2}
$$

Where $\mathrm{D}$ is species domination, ni is the number of $\mathrm{i}$ individuals, and $\mathrm{N}$ is the total number of individual.

The criteria of dominance index value ranges from 0.5 , the lower the lower the index value of dominance the better, because there is no dominant species or community structure in a stable state.

The species dominance index is calculated by the formula Fachrul (2007):

$$
e=\frac{H^{\prime}}{H_{\max }}
$$

Where $e$ is evenness index, $\mathrm{H}^{\prime}$ is species diversity $H_{\max }$ is maximum diversity $(\ln \mathrm{S})$ and $\mathrm{S}$ is the number of species. 
Criteria value of fairness index is around 0,5. Evenness of the species is low if $\mathrm{E}<0.5$, and high if $\mathrm{E}>0.5$ or evenness between species is relatively uniform or the number of individuals of each species is equal.

\section{RESULTS AND DISCUSSION}

The results of this study indicate that flower plants at yellow alder flower planted around palm trees can affect the presence of insects phytophagous and entomophagous. The results showed that the phytophagous insects found in yellow alder flower were classified into 6 orders, and 25 families and entomophagous insects on yellow alder flower were classified into 7 orders, and 15 families. The number of species of insects phytophagous and entomophagous found in yellow alder flower influenced by bloom and wilt yellow alder flower. Species of insects in the blossom phase of the flower of yellow alder flower more found than the wilting phase of the yellow alder flower (Table 1).

In Table 1 it can be seen that phytophagous and entomophagous insects are found in more yellow T. subulata plants than white T. ulmifolia. The number of species of insects phytophagous and entomophagous is influenced by the yellow color on the flowers of plants T. subulata and T. ulmifolia. The yellow color of the flowering of the T. subulata is more than in the T. ulmifolia flower (Fig. 1 A \& B). It is suspected that the interest of the insects in T. subulata is influenced by the dominant yellow flower, and the interest of the insects on $T$. ulmifolia is influenced by the yellow color found in the center of the flower. Judge et al., (2016) study of yellow color can attract populations of phytophagous insects of 23.25 populations followed by a green color of 7.50 populations, and a red color of 6.00 populations. The Sunarno (2011) yellow study can attract many types of phytophagous insects compared to red and green.

In Table 1 it can be seen that the insect phytophagous found in the yellow alder flower in the bloom phase of the flower parts of the plant and the wilting phase of the flower part of the plant. The results showed that the phytophagous insects found in the yellow alder flower phases wilted were affected by the leaf glands (Figure 2 A \& B). According to Steenis (2006) Leaf glands in yellow alder flower have a round shape and are located under the leaves of flowers. The leaf of yellow alder flower gland may affect the presence of a phytophagous insect such as Comfonotus sp. to eat. According to the research conducted by Erniawati and Kahono (2009), leaf glands in flowering plants can produce honey dew that has nectar content that can be used as insect food.

\section{1 index of diversity, dominance and evenness}

The results showed that the phytophagous and entomophagous insects had a relatively different index of diversity, dominance and evenness in the yellow alder flower (Table 2).

The dominant index of the species (D) $<0.5$ indicates that no species dominate other species or community structures in a stable state. The evenness index of the species $(\mathrm{E})>0.5$

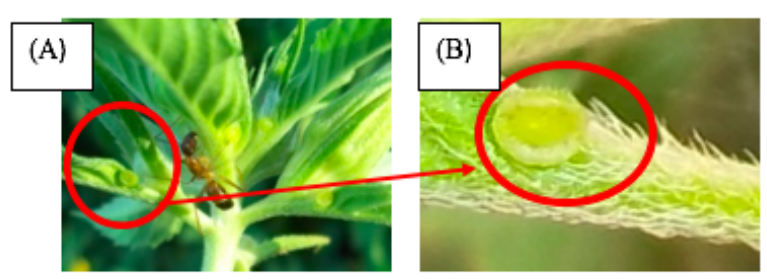

Figure 2. An ant insect on a yellow alder flower (A) Comfonotus sp (B) Leaf glands

Table 2. Index of diversity, dominance and evenness of phytophagous and entomophagous insects present at yellow alder flower

\begin{tabular}{lrr}
\hline \multirow{2}{*}{ Community characteristic } & \multicolumn{2}{c}{ Treatment } \\
\cline { 2 - 3 } & $\begin{array}{c}\text { Turnera } \\
\text { subulata }\end{array}$ & $\begin{array}{l}\text { Turnera } \\
\text { ulmifolia }\end{array}$ \\
\hline Number of individual $(\Sigma)$ & 372 & 223 \\
Diversity index $\left(H^{\prime}\right)$ & 2.912 & 2.603 \\
Domination index $(D)$ & 0.091 & 0.125 \\
Evenness index (E) & 0.752 & 0.738 \\
\hline
\end{tabular}

Description: The species diversity index of H' $>2$ indicates that species diversity is abundant or moderate (Fachrul, 2007).

indicates that evenness between species is relatively uniform or the number of individuals of each species is equal.

The results showed that the index of species diversity, the dominance index, and the evenness index of the phytophagous and entomophagous insects were planted at yellow alder flower in the good category (Table 2). It can be seen from the index value of diversity that is above 2 , the dominance index is close to 0.1 and the evenness index is above 0.7 . These figures suggest that the diversity of species of phytophagous and entomophagous insects at yellow alder flower is quite high, no species are predominant and the fairness of individuals or species is high enough. The relatively low index of species dominance shows that no species dominate the community, and also the high-evenness index provides information that the species in the community are spreading flat.

\subsection{Pearson correlation coefficient}

The results showed that abiotic factors of temperature, humidity and light intensity there are positive (correlated) and there is a negative (not correlated). In each region and plant seen that the temperature does not affect the number of insects found. Moisture and light intensity can affect the number of insects found (Table 3).

The results showed that the number of phytophagous and entomophagous insects at yellow alder flower can be influenced by species and areas near and far from the water. In (Table 3) it can be seen that the humidity of the environment in T. subulata near the waters has a significance value of $0.01<0.05$. It shows 
Table 3. Significance values Pearson correlation between abiotic factors (temperature, humidity and light intensity) with total individual phytophagous and entomophagous insects on yellow alder flower

\begin{tabular}{clcc}
\hline \multirow{2}{*}{ Research Location } & \multicolumn{3}{c}{ Abiotic factor } \\
\cline { 2 - 4 } & Temperature & Humidity & Light intensity \\
\cline { 2 - 4 } & -0.88 & Area A (Near water area) \\
\hline Turnera subulata & -0.19 & 0.01 & 0.34 \\
Turnera ulmifolia & \multicolumn{4}{c}{0.56} \\
Turnera subulata & -0.28 & Area B (Far from water area) \\
Turnera ulmifolia & -0.63 & -0.02 & -0.04 \\
& & -0.34 & 0.29 \\
\hline
\end{tabular}

Description: if the value of significance $<0.05$, then correlated, If the significance value $>0.05$, then not correlated

there is a correlation between abiotic factors of humidity to the number of insects. Environmental humidity in T. subulata area far from water has significance value $-0.34>0,05$. It shows that there is no correlation between abiotic factors of humidity to the number of insects.

\section{CONCLUSIONS}

T. subulata and T. ulmifolia plant species planted around oil palm trees have relatively different effects in inviting the presence of species of phytophagous and entomophagous insects. Turnera subulata plants can attract 6 phylogenetic insects, 25 families and 220 heads, and Turnera ulmifolia plants can attract 7 phytophagous insects, 15 families and 108 heads. T. subulata can attract twice as many phytophagous and entomophagous insects than T. ulmifolia. T. subulata and T. ulmifolia plants can maintain the phytophagous and entomophagous insect communities in oil palm cultivation. It can be seen through high diversity index. It can be seen through high species diversity index $(2,603-2,912)$, low dominance index $(0,091-0,125)$, and high evenness index $(0,738-0,752)$. Abiotic factors of humidity play an important role in influencing the presence of insects with correlation coefficient value of 0.01 in $\mathrm{T}$. subulata area near river waters.

\section{REFERENCES}

Anderson, B. P. (1998). The Insects Of Australia. Melbourne University Press, Australia

Asmani, N. (2014). Kelapa Sawit Komoditas Unggulan Sumatera Selatan Yang Ramah Lingkungan. In Seminar GAPKI Sumatera selatan : 6
Erniawati and S. Kahono (2009). Peranan Tumbuhan Liar Dalam Konservasi Serangga Penyerbuk Ordo Hymenoptera. J. Teknik Lingkungan, 10(2); 195-203

Fachrul, M. F. (2007). Metode Saampling Bioekologi. Bumi aksara, Jakarta

Kalshoven, L. (1981). Pest of Crops In Indonesia. Revised and translated by P.A. van der Laan. PT Ichtiar Baru-Van Hoeve

Kurniawati, N. and E. Martono (2015). Peran Tumbuhan Berbunga sebagai Media Konservasi Artropoda Musuh Alami The Role of Flowering Plantsin Conserving Arthropod Natural Enemies. Perlindungan Tanaman Indonesia, 19(2); 53-59

Magurran, A. E. (1998). Ecological Diversity and Its Measurant. Princenton University Press

Nasution, S. H., C. Hanum, and J. Ginting (2014). Pertumbuhan Bibit Kelapa Sawit (Elaeis guineensis Jacq.) Pada Berbagai Perbandingan Media Tanam Solid Decanter Dan Tandan Kosong Kelapa Sawit Pada Sistem Single Stage. Online Agroekoteknologi, 2(2); 691-701

Steenis, V. (2006). Flora. Pradya Paramitha

Tyas, I. L. M., A. P. P. Sari, M. Saefi, and W. C. Adi (2016). Distribusi Temporal Arthropoda Pada Tumbuhan Liar Krokot (Portulaca oleracea L.) Di Lahan Pertanian Tomat Desa. In Prosiding Seminar Nasional II Tahun 2016, Kerjasama Prodi Pendidikan Biologi Fkip Dengan Pusat Studi Lingkungan Dan Kependudukan (Pslk) Universitas Muhammadiyah Malang. pages 755-763

Zahradink, J., F. Severa, M. J, and M. Vana (1991). The Ilustrated Book Of Insect. Great Britain:310 